\title{
Liver Disorders in Pregnancy: A Fetomaternal Outcome
}

\author{
Sathyavrathan Nair Vinayachandran ${ }^{1}$, Kathot Anaswara ${ }^{2}$
}

\begin{abstract}
Liver disease is a potentially serious complication seen in pregnancy occurring more in developing countries. The advances in understanding of the diseases with timely diagnosis and management have resulted in a significant reduction in the adverse outcome occurring both in the mother and the fetus.

Aim and objective: To study the fetomaternal outcome due to the various causes of liver diseases in pregnancy.

Materials and methods:

- Study design: Observational prospective study. Study setting: The study was conducted in the Department of Obstetrics and Gynaecology, Government Medical College, Kozhikode from March 2016 to September 2017, a total of 18 months.

- Study subjects: Pregnant patients with liver diseases who presented as jaundice and attended the Department of Obstetrics and Gynaecology during the study period were included in the study. Nonpregnant ladies with jaundice were excluded from the study.

- Methodology: A detailed history, clinical examination, and necessary investigations were done for all cases.

Results: The observations from this study were as follows: The total number of deliveries in this period was 24060 . The number of cases with liver diseases complicating pregnancy was 52 . Thus the incidence of liver diseases complicating pregnancy was $0.22 \%$. In this study, out of the 52 cases of liver diseases complicating pregnancy, 18 (34.6\%) were found to be due to hemolysis, elevated liver enzymes, and low platelet count (HELLP) syndrome. Maximum number of cases were between 34 weeks and 37 weeks of gestation (40.4\%). Of the total 52 cases, 23 underwent cesarean delivery and 29 had vaginal delivery. There was one case of maternal death which was due to fulminant hepatic failure in a case of hepatitis A. The perinatal mortality rate in this study was 122 per 1,000 cases of liver diseases.

Conclusion: Early diagnosis and prompt management of cases may decrease the perinatal and maternal morbidity as well as mortality to a greater extent.

Keywords: Fetomaternal outcome, Hemolysis, elevated liver enzymes, and low platelet count syndrome, Liver disorders.

Journal of South Asian Federation of Obstetrics and Gynaecology (2020): 10.5005/jp-journals-10006-1788
\end{abstract}

\section{INTRODUCTION}

Liver disease is a rare but potentially serious complication seen in pregnancy occurring more in developing countries than in developed countries. Causes for liver disorders in pregnancy include causes specific to pregnancy like hemolysis, elevated liver enzymes, and low platelet count (HELLP) syndrome; acute fatty liver of pregnancy (AFLP); intrahepatic cholestasis of pregnancy (ICP); hyperemesis gravidarum and other diseases which occur incidentally in pregnancy like viral hepatitis. The advances in understanding of the diseases with timely diagnosis and management have resulted in a significant reduction in the adverse outcome occurring both in the mother and the fetus.

\section{Aim and Objective}

To study the fetomaternal outcome due to the various causes of jaundice in pregnancy.

\section{Materials and Methods}

\section{Study Design}

Observational prospective study.

\section{Study Setting}

The study was conducted in the Department of Obstetrics and Gynaecology, Government Medical College, Kozhikode, India.

\section{Study Period}

From March 2016 to September 2017, a total of 18 months.
1,2Department of Obstetrics and Gynaecology, Government Medical College, Kozhikode, Kerala, India

Corresponding Author: Kathot Anaswara, Department of Obstetrics and Gynaecology, Government Medical College, Kozhikode, Kerala, India, Phone: +91 9745088055, e-mail: anaswarakathot@gmail.com

How to cite this article: Vinayachandran SN, Anaswara K. Liver Disorders in Pregnancy: A Fetomaternal Outcome. J South Asian Feder Obst Gynae 2020;12(3):167-171.

Source of support: Nil

Conflict of interest: None

\section{Study Subjects}

Pregnant patients with liver diseases who presented as jaundice and attended the Department of Obstetrics and Gynaecology during the study period were included in the study. Nonpregnant ladies with jaundice were excluded from the study.

\section{Methods}

A detailed history, clinical examination, and necessary investigations were done for all cases. The cases were followed through delivery to one week postpartum. The investigations included complete blood count; liver function test; renal function test; blood sugar values; coagulation profile; serology for hepatitis $A, B, C$, and E; autoantibodies; and ultrasonography (USG) abdomen which are the routine investigations done in our institution for a case of jaundice complicating pregnancy. Expert opinion was sought for all patients from the Department of Gastroenterology and our management was modified accordingly. The data were analyzed to find out the

(c) The Author(s). 2020 Open Access This article is distributed under the terms of the Creative Commons Attribution 4.0 International License (https://creativecommons. org/licenses/by-nc/4.0/), which permits unrestricted use, distribution, and non-commercial reproduction in any medium, provided you give appropriate credit to the original author(s) and the source, provide a link to the Creative Commons license, and indicate if changes were made. The Creative Commons Public Domain Dedication waiver (http://creativecommons.org/publicdomain/zero/1.0/) applies to the data made available in this article, unless otherwise stated. 
percentage distribution of the cases, the course of pregnancy, and the maternal and fetal complications as per the pro forma. Maternal outcomes analyzed include postpartum hemorrhage (PPH), disseminated intravascular coagulation (DIC), renal failure, cerebral edema, pulmonary edema, hepatic encephalopathy, pleural effusion, abruptio placenta, and maternal death. Fetal outcomes include intrautrine death (IUD), neonatal death (NND), and prematurity.

\section{Results}

The observations from this study were as follows: The total number of deliveries in this period was 24,060 . The number of cases with jaundice complicating pregnancy was 52 . Thus, the incidence of liver diseases complicating pregnancy was $0.22 \%$.

\section{Etiology of Jaundice}

In this study, out of the 52 cases of liver disease complicating pregnancy, 18 (34.6\%) were found to be due to HELLP syndrome. This accounted for the maximum number of liver disorders complicating pregnancy. Viral hepatitis was found in seventeen $(32.7 \%)$ of them which was the second most common cause. AFLP was seen in seven cases (13.5\%). Figure 1 shows the causes of liver disorders in pregnancy.

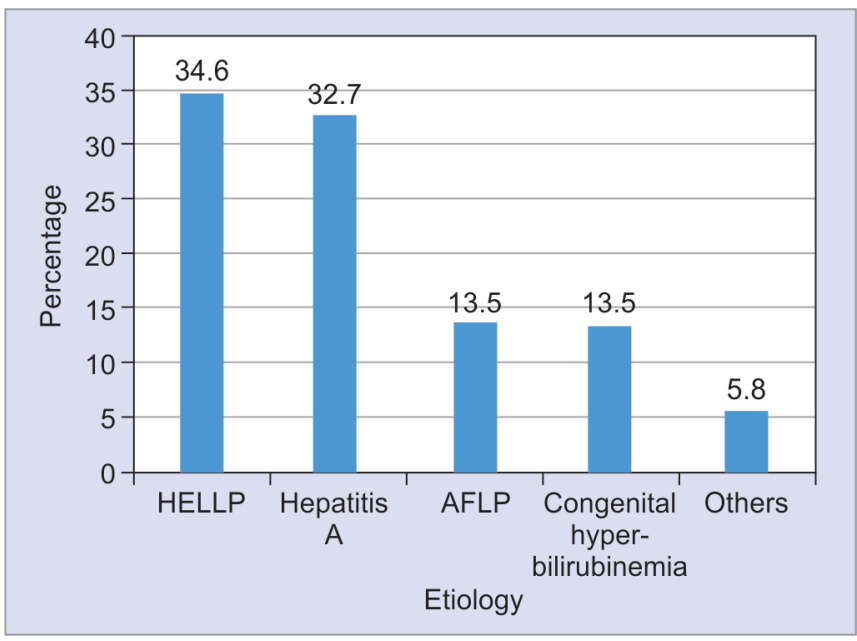

Fig. 1: Etiology of jaundice

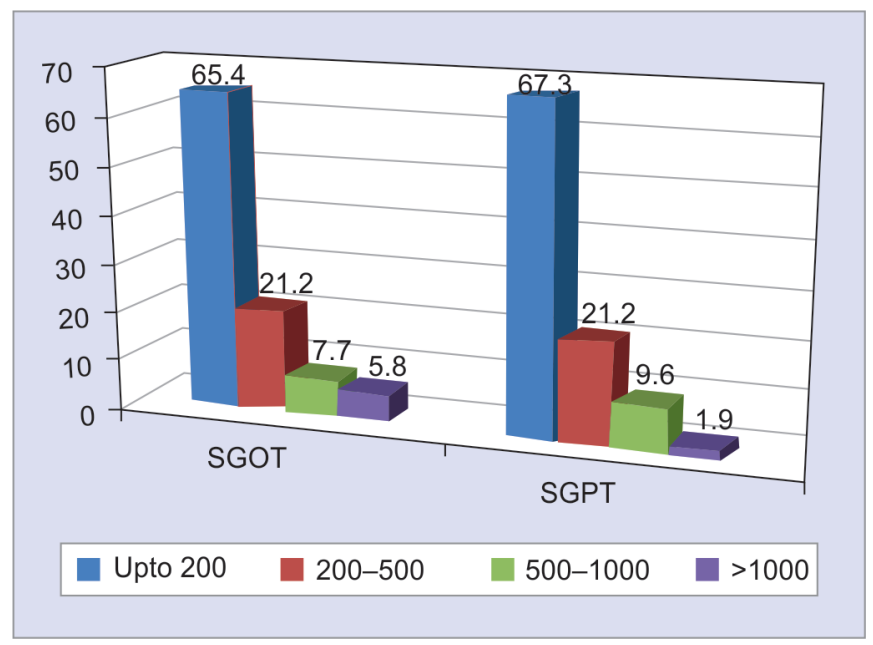

Fig. 3: Range of SGOT/SGPT (U/L)

\section{Gestational Age at Diagnosis}

Figure 2 shows the relationship between gestational age and liver disorders complicating pregnancy. Maximum number of cases were between 34 weeks and 37 weeks of gestation (40.4\%).

\section{Liver Function Tests}

Table 1 shows the range of total bilirubin obtained in this study. $69.2 \%$ of women had total bilirubin in the range of $2-5.9 \mathrm{mg} / \mathrm{dL}$. Only one woman with AFLP had a bilirubin value of more than 20 $\mathrm{mg} / \mathrm{dL}$.

Figure 3 shows the range of liver enzymes. Majority of the women had a value up to $200 \mathrm{U} / \mathrm{L}$.

Figure 4 shows the range of lactate dehydrogenase (LDH). $75 \%$ of the women had an LDH value of less than $1000 \mathrm{U} / \mathrm{L}$.

Table 1: Distribution of total bilirubin $(\mathrm{mg} / \mathrm{dL})$

\begin{tabular}{lll}
\hline Total bilirubin $(\mathrm{mg} / \mathrm{dL})$ & Number of cases & Percentage \\
\hline $2-5.9$ & 36 & 69.2 \\
$6-9.9$ & 9 & 17.3 \\
$10-19.9$ & 6 & 11.5 \\
$>20$ & 1 & 1.9 \\
\hline
\end{tabular}

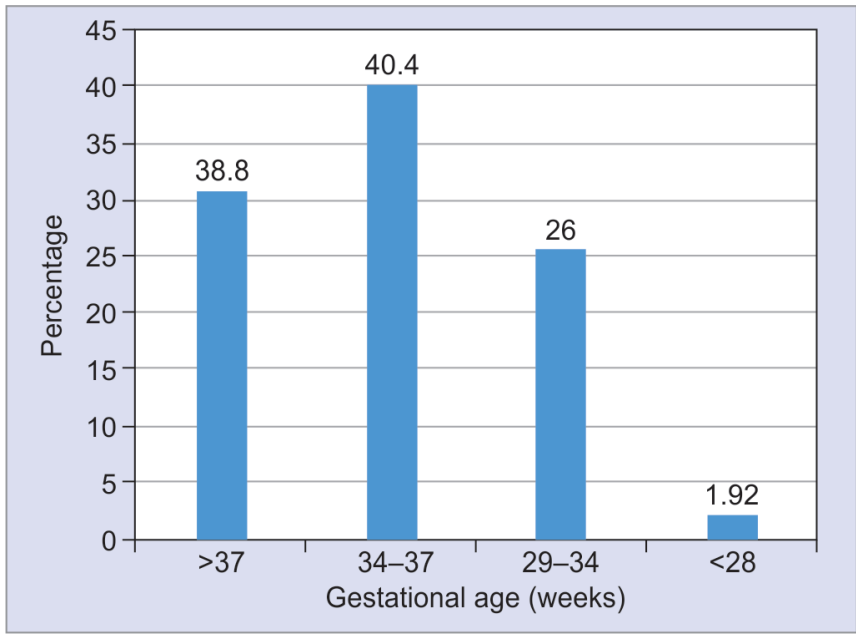

Fig. 2: Relationship between gestational age and liver disorders in pregnancy

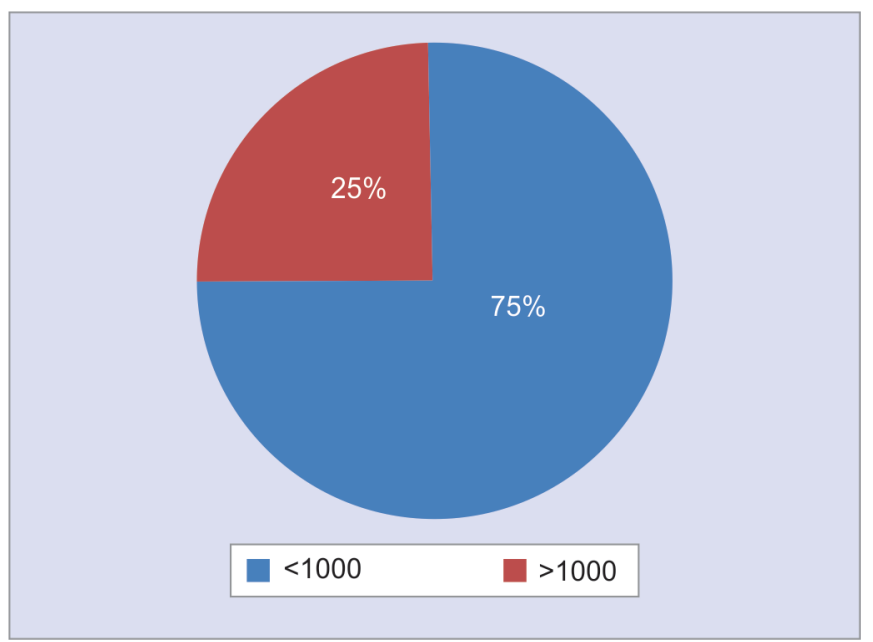

Fig. 4: Range of $L D H(U / L)$ 


\begin{tabular}{lll}
\multicolumn{2}{l}{ Table 2: Distribution of total protein $(\mathrm{g} / \mathrm{dL})$} \\
\hline Total protein $(\mathrm{g} / \mathrm{dL})$ & Number of cases & Percentage \\
\hline $6-8$ & 12 & 23.1 \\
$5-5.9$ & 32 & 61.5 \\
$<5$ & 8 & 15.4 \\
\hline
\end{tabular}

Table 3: Cesarean section-indications

\begin{tabular}{ll}
\hline Indications & Number of cases \\
\hline Previous CS & 7 \\
AFLP, Unfavorable cervix & 4 \\
HELLP, Unfavorable cervix & 4 \\
HELLP, grade II MSAF & 1 \\
Arrest of descent & 2 \\
Fetal distress & 2 \\
Failed induction & 1 \\
Failure to progress & 1 \\
Triplet & 1 \\
\hline
\end{tabular}

Table 4: Maternal complications

\begin{tabular}{lll}
\hline & Number of cases & Disease \\
\hline Atonic PPH & 2 & AFLP \\
AKI & 2 & HELLP \\
Abruptio placenta & 1 & AFLP \\
Wound infection & 2 & Hepatitis, AFLP \\
DIC & 3 & HELLP, AFLP, Hepa- \\
& & titis \\
Pleural effusion & 2 & HELLP \\
Pulmonary edema & 1 & HELLP \\
Maternal death & 1 & Hepatitis A with \\
& & acute hepatic failure \\
\hline
\end{tabular}

\section{Range of Total Proteins}

Table 2 shows the range of total proteins. $61.5 \%$ of women had a total protein of $5-5.9 \mathrm{~g} / \mathrm{dL}$.

\section{Mode of Delivery}

Of the total 52 cases, 23 underwent cesarean delivery and 29 had vaginal delivery. Lower segment cesarean section (LSCS) was done mainly for obstetric indication.

\section{Vaginal Delivery: Spontaneous vs Induced}

Out of the 29 vaginal deliveries, twenty-three had spontaneous delivery and six of them were induced. Of the women who were induced, cesarean section (CS) had to be done for one case, for failed induction.

\section{Indications for CS}

Table 3 shows the indications for CSs.

Of the seven cases of previous CS, five were cases of HELLP syndrome, one was antepartum eclampsia, and another, a case of congenital hyperbilirubinemia. Out of the two cases of arrest of descent, one case was that of hepatitis A and the other was congenital hyperbilirubinemia. Two cases of CS were done for fetal distress. One was a case of hepatitis A and the other a case of HELLP syndrome. In triplets, CS was done for obstetric reasons.

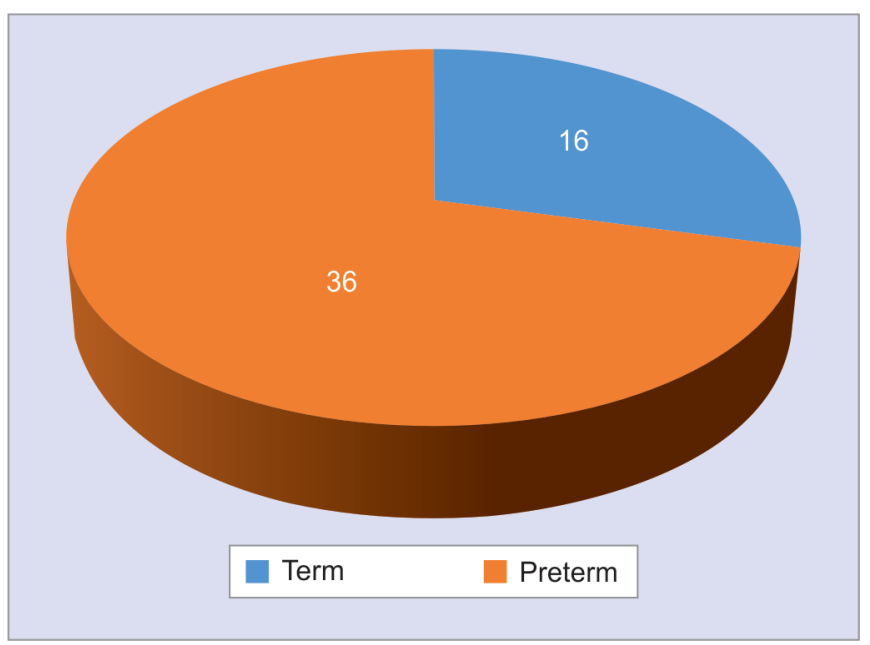

Fig. 5: Term vs preterm

\section{Maternal Complications}

Table 4 shows the maternal complications in women with liver disorders.

There were two cases of atonic PPH both occurred during CS. One was done for triplet pregnancy and the other for monochorionic diamniotic (MCDA) twins. There was one case of abruptio placenta in one case of AFLP. There were two cases of wound infections. One was an episiotomy wound infection in a woman with hepatitis $A$ and the other a postoperative wound infection in a woman with AFLP. There was one case of maternal death which was due to fulminant hepatic failure in a case of hepatitis $A$.

\section{Condition of the Baby}

Term vs Preterm

Figure 5 shows that 36 out of 52 deliveries were preterm deliveries of which 16 were spontaneous,14 underwent cesarean delivery, and 6 were induced.

\section{Birth Weight Distribution}

Figure 6 shows the birth weight distribution of babies. Twenty-one percent of the babies had a birth weight of $1-1.5 \mathrm{~kg}$.

\section{Perinatal Mortality}

Table 5 shows the causes of perinatal mortality. The perinatal mortality rate in this study was 122 per 1,000 cases of liver diseases.

\section{Discussion}

This study on liver diseases in pregnancy was conducted in The Department of Obstetrics and Gynaecology, Government Medical College, Kozhikode, over a period of one and half years from March 2016 to September 2017. Women who presented with jaundice were included in this study. The total number of cases over this time period was 52 out of 24,060 deliveries.

Incidence of liver disease varies in developing and developed countries, the incidence being more in developing countries. In this study, the incidence of liver diseases complicating pregnancy was found to be $0.22 \%$. This observation tallies with various other studies done in other parts of the country. In 1992, Sarkar et al. ${ }^{1}$ reported an incidence of $0.23 \%$. In 2016 , a study conducted by Krishnamoorthy et al. ${ }^{2}$ the incidence of jaundice in pregnancy was 


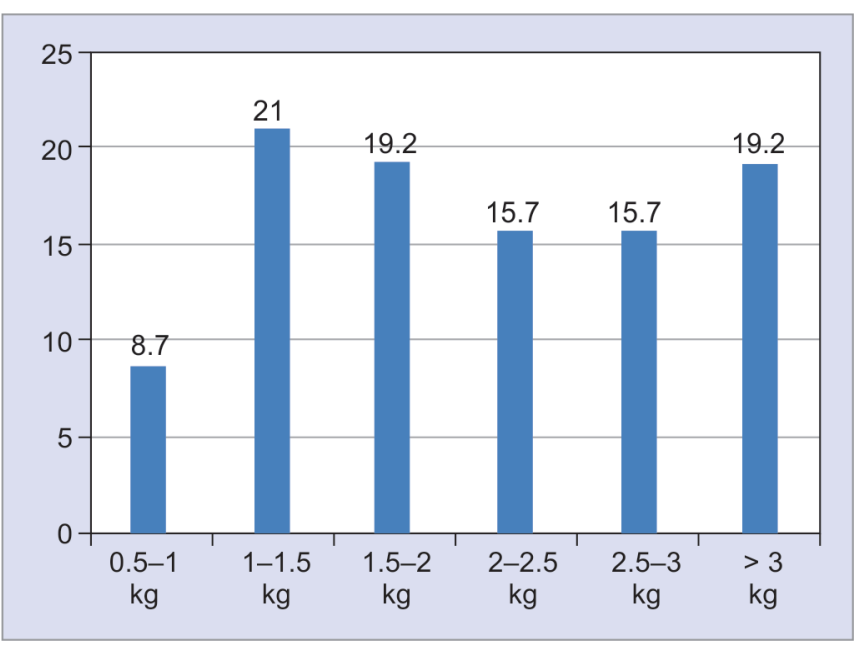

Fig. 6: Birth weight distribution

Table 5: Perinatal mortality

\begin{tabular}{|c|c|c|c|c|}
\hline & Case & $\begin{array}{l}\text { Gestational } \\
\text { age }\end{array}$ & $\begin{array}{l}\text { Birth weight } \\
\text { (g) }\end{array}$ & $\begin{array}{l}\text { Cause of } \\
\text { death }\end{array}$ \\
\hline IUD FSB & HELLP & $\begin{array}{l}30 \text { weeks } 3 \\
\text { days }\end{array}$ & 900 & \\
\hline IUD FSB & HELLP & $\begin{array}{l}31 \text { weeks } 6 \\
\text { days }\end{array}$ & 1,290 & \\
\hline NND & HELLP & $\begin{array}{l}26 \text { weeks } 2 \\
\text { days }\end{array}$ & 710 & Prematurity \\
\hline NND & HELLP & 28 weeks & 800 & Prematurity \\
\hline NND & AFLP & $\begin{array}{l}31 \text { weeks } 6 \\
\text { days }\end{array}$ & 1,500 & Sepsis \\
\hline NND & Hepatitis A & 33 weeks & 2,570 & $\begin{array}{l}\text { Pulmonary } \\
\text { embolism } \\
\text { to mother } \\
\text { (prior to } \\
\text { delivery) }\end{array}$ \\
\hline NND & AFLP & $\begin{array}{l}33 \text { weeks } 5 \\
\text { days }\end{array}$ & $2,050 / 1,990$ & $\begin{array}{l}\text { Perinatal } \\
\text { asphyxia } \\
\text { (abruptio } \\
\text { placenta) }\end{array}$ \\
\hline
\end{tabular}

$0.29 \%$. In another study conducted by Neema et al. at Wardha ${ }^{3}$ over a period of 6 years, published in 2013, reported a slightly higher incidence of $0.4 \%$. In a study conducted in 2016 at Seth Gordhandas Sundardas Medical College, ${ }^{4}$ the incidence reported was $0.81 \%$. This shows that the incidence of liver diseases not only varies globally but varies from region to region within the same country.

Coming to the pattern of disease distribution, HELLP syndrome was the commonest cause of liver disorders in this institution. The next most common cause was hepatitis A. Of the 52 cases, 18 (34.6\%) were due to HELLP syndrome and 17 (32.7\%) were due to viral hepatitis. All cases of viral hepatitis were caused by hepatitis A virus. However, one patient with hepatitis A infection had a coexistent hepatitis E weak positivity and one patient had an associated sickle cell disease. Thirteen percentage of the cases were due to AFLP and an equal number of cases were congenital hyperbilirubinemia. There were one case each of cholangitis, cholelithiasis, and cholangiocarcinoma. Earlier studies showed viral hepatitis as the most common cause of jaundice in pregnancy Meena et al. ${ }^{4}$ and Neema et al. ${ }^{3}$
Krishnamoorthy et al. ${ }^{2}$ reported an incidence of $51 \%$ of cases of hepatitis in their study and $13.72 \%$ of cases of HELLP syndrome. Shukla et al. ${ }^{5}$ reported $57 \%$ and Harshad et al. ${ }^{6}$ reported $47 \%$ cases of viral hepatitis in their study. A decrease in incidence of hepatitis is noticed in recent years. This may be due to the increased public awareness about personal and community hygiene. There were many HBsAg positive cases in this study period but all of them were in the chronic carrier state and none in the acute hepatitis stage, hence these cases were not included in the study.

The total bilirubin level showed only a mild elevation (2-5.9 $\mathrm{mg} / \mathrm{dL}$ ) in $69.2 \%$ of cases. The bilirubin level was $6-9.9 \mathrm{mg} / \mathrm{dL}$ in $17.3 \%$. A higher level of $10-19.9 \mathrm{mg} / \mathrm{dl}$ was found in only $11.5 \%$ and a value of more than $20 \mathrm{mg} / \mathrm{dl}$ was found in only one (1.92\%) case which was a case of AFLP. In the study by Krishnamoorthy et al., ${ }^{2}$ the level of bilirubin varied widely between $2.8 \mathrm{mg} / \mathrm{dL}$ and $18.4 \mathrm{mg} / \mathrm{dL}$ and $7.84 \%$ of patients had high serum bilirubin, more than $16 \mathrm{mg} / \mathrm{dl}$. In this study, the serum glutamic oxaloacetic transaminase (SGOT)/serum glutamic pyruvic transaminase (SGPT) levels in most of the cases (65.4\% and $67.3 \%$ respectively) showed a value less than $200 \mathrm{U} / \mathrm{L}$. In a study on fetomaternal outcome in jaundice in pregnancy, by Nagaria et al. ${ }^{7} 75 \%$ of the cases had SGOT/ SGPT levels of less than $500 \mathrm{U} / \mathrm{L}$. Similar results were seen in the study conducted by Krishnamoorthy et al. ${ }^{2}$ where $93 \%$ of the cases had an SGPT value of less than $500 \mathrm{U} / \mathrm{L}$. This study showed SGOT values of more than 1000 only in cases of hepatitis A (3 cases) and SGPT value of more than $1000 \mathrm{U} / \mathrm{L}$ was seen in one case of HELLP syndrome only. The total protein levels were in the normal range in $23.1 \%$. A total protein level of $5-5.9 \mathrm{~g} / \mathrm{dL}$ was seen in $61.5 \%$ of cases and $15.4 \%$ had a total protein value of less than $5 \mathrm{~g} / \mathrm{dL}$.

Analyzing the mode of delivery 29 (55.7\%) out of 52 underwent vaginal delivery out of which 23 had spontaneous onset of labor. Six had to be induced. There were $23(44.2 \%)$ cases of CSs of which seven were because of a previous CS. Four cases each were done in view of unfavorable cervix in cases of HELLP syndrome and AFLP. In one case of HELLP syndrome CS was done in view of grade II meconium stained liquor. Two cases underwent CS in view of arrest of descent, two were done in view of fetal distress. One case had undergone CS for failed induction, one case for failure to progress and one case was a triplet pregnancy in a case of AFLP. In the study by Krishnamoorthy et al. ${ }^{2} 70 \%$ of patients delivered vaginally. $21.56 \%$ patients had LSCS. Satia ${ }^{4}$ reported a vaginal delivery rate of $69 \%$ in their study.

Maternal outcome was studied in terms of mortality and complications like PPH, DIC, renal failure, abruptio placentae, and wound infection. Thirteen women had complications. Presence of complications was seen more with HELLP syndrome and AFLP. There were two cases of atonic PPH that occurred in AFLP cases with multiple gestations who had undergone CS. Other complications seen associated with HELLP syndrome include DIC, pleural effusion, and pulmonary edema. AFLP was seen associated with $\mathrm{PPH}, \mathrm{DIC}$, abruption placenta, and postoperative wound infection. Hepatitis was seen associated with one case of DIC and one case of episiotomy wound infection. A much higher rate of complications was seen in the study conducted by Krishnamoorthy et al. ${ }^{2}$ (35\%) and by Satia et al. ${ }^{7}$ (55\%).

There was one case of maternal death which was a case of hepatitis A. She was referred from Gastroenterology department at 29 weeks gestation with resolved hepatic encephalopathy and resolving hepatic failure. She had a spontaneous preterm delivery and was transferred back to Gastroenterology department from 
where her liver parameters worsened and she went into acute liver failure and could not survive. One patient with cholangiocarcinoma who presented as obstructive jaundice delivered uneventfully and was referred to surgery department for further management. Maternal mortality of $7.8 \%$ (4 out of 51 patients) was reported by Krishnamoorthy et al. ${ }^{2}$ Two deaths were due to AFLP, one died of HELLP syndrome, and one due to rupture of esophageal varices. In the study by Pranatti Mitta, ${ }^{8}$ the maternal mortality was $4.76 \%$.

The total number of preterm deliveries was $36(69.2 \%)$ whereas the total numbers of term deliveries were 16 cases $(30.7 \%)$. This shows a higher incidence of preterm deliveries when compared to the general population. Most of the studies have shown a higher incidence of preterm deliveries than in the general population. A study by Kumar et al. showed an incidence of $66.6 \%{ }^{6}$

When analyzing the birth weight distribution, it was found that a smaller number of babies were born with baby weight between $500 \mathrm{~g}$ and $1 \mathrm{~kg}$ (8.7\%). Sixty four percent of the babies weighed less than $2.5 \mathrm{~kg}$. This shows that most of the babies were low birth weight. This tally with the findings of the study conducted by Mitta. ${ }^{8}$ The perinatal mortality in their study was $30.7 \%$. In the present study, out of the total seven perinatal deaths, two were IUD and others were NND's. Three cases were HELLP syndrome and three were AFLP cases and one was a case of hepatitis. The perinatal mortality rate was 122 per 1000 cases of liver diseases. Our institutional perinatal mortality rate was 21 per 1000 live births.

\section{CONCLUSION}

The incidence of liver diseases complicating pregnancy in this study was $0.22 \%$. The most common cause of liver diseases in this study was HELLP syndrome followed by hepatitis $A$.

Preterm deliveries were common in this study. Most of the women had vaginal delivery. Maternal complications were seen more in cases of HELLP syndrome and AFLP. Early detection of hypertension and its timely management may help in reducing the maternal complications seen with HELLP syndrome. The perinatal mortality rate seen in this study was 122 per 1000 cases of liver diseases which is higher than that of the general population.
There was one case of maternal death due to fulminant hepatitis in a case of hepatitis $A$.

Early diagnosis and prompt management of cases may decrease the perinatal and maternal morbidity as well as mortality to a greater extent. Further studies are required to assess whether pregnancy can be prolonged in cases of infective hepatitis in order to improve the perinatal outcome.

\section{Acknowledgments}

The authors would like to thank the Department of Obstetrics and Gynaecology and administration of Government Medical College, Kozhikode, Kerala, for permission to study and providing facility to carry out the work.

\section{Ethical Approval}

Approved by institutional ethics committee.

\section{References}

1. Sarkar CS, Giri AK, Maity TK, et al. Jaundice in pregnancy: a clinical study. J Indian Medical Assoc 1992;90:117-118.

2. Krishnamoorthy J, Murugesan A. Jaundice during pregnancy: maternal and fetal outcome. Int J Reproduct, Contracept, Obstet Gynecol 2017;5:2541-2545.

3. Acharya N, Acharya S, Shukla S, et al. Study of jaundice in pregnancy. Global J Med Res 2014. 13.

4. Satia MN, Jandhyala M. A study of fetomaternal outcomes in cases of jaundice at a tertiary care centre. Int J Reprod, Contracept, Obstet Gynecol 2017;5:2352-2357.

5. Shukla $S$, Mehta $G$, Jais $M$, et al. A prospective study on acute viral hepatitis in pregnancy; seroprevalence, and fetomaternal outcome of 100 cases. J biosci Tech 2011;2:279-286.

6. Devarbhavi $\mathrm{H}$, Kremers WK, Dierkhising R, et al. Pregnancy-associated acute liver disease and acute viral hepatitis: differentiation, course and outcome. J Hepatol 2008;49(6):930-935. DOI: 10.1016/j. jhep.2008.07.030.

7. Nagaria T, Agarwal $S$, et al. Fetomaternal outcome in jaundice during pregnancy. J Obstet Gynecol India 2005;55:424-427.

8. Mitta P, Rao SV. Fetomaternal outcome in jaundice complicating pregnancy. IOSR J Dent Med Sci 2016;15(Issue 10 Ver. VI):72-76. 